\title{
Putting Sociology to Work in Winnersville, USA $^{1}$
}

\author{
Mark Patrick George ${ }^{2}$
}

[Article copies available for a fee from The Transformative Studies Institute. E-mail address: journal@transformativestudies.org Website: http://www.transformativestudies.org (C2011 by The Transformative Studies Institute. All rights reserved.]

One of the things that attracted me to sociology was that it helped me "make sense" of the world I found myself in as a young white man growing up in the Deep South. So when I stumbled across sociology, as someone who had changed his major five times and didn't know why he was going to college, it was liberating. First, sociology showed me that it is good to ask critical questions and to question matters others accept as "normal." Second, sociology helped me find answers to questions that plagued me by teaching me to recognize the broader social forces that shape our lives-you know, that "sociological imagination" (Mills, 1959) professors are always going on about! For example, too often we simply fault poor people for being poor instead of understanding why they are poor, a practice William Ryan (1971) labeled "blaming the victim." Lastly, it freed me from an assortment of unnecessary fears and judgments I carried about others who are different from me by revealing that social differences are not inherently dangerous or "deviant" (Lorde 1984) but in most cases are the spice that makes life interesting and vibrant. For these reasons, I became a sociologist.

\footnotetext{
${ }^{1}$ Mark Patrick George, Sociologists in Action pp. 158-163, copyright 2011 by Pine Forge Press, Reprinted by Permission of Pine Forge Inc.

${ }^{2}$ Mark Patrick George is an applied sociologist from Valdosta, Georgia, where he currently serves as an assistant professor in the Department of Sociology at Valdosta State University. His scholarly attention and community organizing work focuses on antiracist, antisexist, and anti-heterosexist initiatives in the Southeast. In addition to his academic pursuits, he serves as the faculty advisor for the Zeta Chapter of Alpha Kappa Delta and coordinates the Mary Turner Project (www.maryturner.org), a joint student/community organization created to addresses issues of racial injustice in South Georgia. He also serves as the Education Committee Chairperson for the Lowndes/Valdosta Chapter of the Southern Christian Leadership Conference.
} 